\title{
Exploring the Impact of Knowledge Sharing and Organizational Culture on Teacher Innovation Capability
}

\author{
Eva Agistiawati ${ }^{1}$, Masduki Asbari ${ }^{2} *$, Sucipto Basuki ${ }^{3}$, Teguh Yuwono ${ }^{4}$, Gusli Chidir ${ }^{5}$, Mustofa $^{6}$, \\ Nelson Silitonga ${ }^{7}$, Didi Sutardi ${ }^{8}$, Dewiana Novitasari ${ }^{9}$ \\ 1,2,3,5 STMIK Insan Pembangunan, Indonesia \\ 4,6,7,8,9 Sekolah Tinggi Ilmu Ekonomi Insan Pembangunan, Indonesia \\ ${ }^{2}$ Pelita Harapan University, Indonesia
}

\begin{abstract}
This research aims to measure the effect of tacit and explicit knowledge on teacher innovation capability in Indonesia mediated by organizational culture. Data collection was carried out by simple random sampling to 1080 population of teachers in Kecamatan Panongan Tangerang Indonesia. The returned and valid questionnaire results were 453 samples. Data processing was using SEM method with Smart PLS 3.0 software. The results of this research are tacit knowledge sharing has a positive and significant effect on teacher innovation capability, both directly and through mediating organizational culture. While explicit knowledge sharing only has a positive and significant effect on teacher innovation capability through organizational culture mediation. This novel research is proposing a model to build teacher innovation capability among teachers through tacit \& explicit knowledge sharing with organizational culture as mediation. This research can pave the way to improve teacher readiness in facing the education 4.0. era.
\end{abstract}

Keywords -- Explicit knowledge, knowledge sharing, teacher innovation capability, organizational culture, tacit knowledge

\section{INTRODUCTION}

A new challenge that is currently affecting education is a dramatic change that has come from industrial revolution 4.0. This industrial revolution requires more qualified, agile, adaptive and responsive human resources to rapid change. The world of education is facing rapid economic, social, political and technological change. Therefore, schools must be flexible to be able to adapt to changing situations and contexts. Schools and other educational institutions need an environment that continues to grow positively and conducively in global human resource competition (Asbari, 2015, 2018; Asbari, Chi Hyun, Wijayanti, Imelda, \& Purwanto, 2020; Asbari, Hyun, Wijayanti, Winanti, Fayzhall, et al., 2020; Sopa et al., 2020). Therefore, it cannot be denied that schools need a synergy between teachers and the work environment that is able to make continuous improvements in innovation and performance. The point is that in this era of knowledge economy emerging knowledge societies which need innovation and flexibility as energy to survive the competition. Therefore, the strategic development of educational institutions in the future is to increase knowledge resources, especially teachers, which open space for innovation and growth (Asbari, Fayzhall, Goestjahjanti, et al., 2020; Fayzhall et al., 2020; Goestjahjanti et al. ., 2020).

To ensure that educational institutions, especially schools can be competitive and adaptive, teachers need to be directed and involved in increasing school performance. Teachers must be empowered and empowering. As a result, schools must manifest into a true organizational culture. Organizational culture that empowers teachers is one of the main elements of school transformation as well as teachers as instruments of civilization. The shape of the school as an organizational culture is very important for educational institutions that operate in environments with rapid and unexpected changes. So that, the speed of response to change, becomes an absolute requirement to create human resources, students who are competitive and win global HR competition.

The knowledge of individual teachers and schools becomes intellectual capital which quickly becomes a new icon that illustrates the economic value of a school. This is the new paradigm adapted from industrial revolution 4.0. Dependence on traditional productive assets such as buildings, land and other 
tangible assets is no longer a major investment contribution in the future. Productive and sustainable assets in the future are intangible assets in the form of knowledge inherent in the teacher. This research seeks to understand the effect of the learning and knowledge sharing (tacit and explicit knowledge) of teachers in Indonesia that are associated with increasing the teacher innovation capability.

\section{A. Research Hypothesis}

Based on the problem formulation, theoretical research, and conceptual framework of the research hypothesis as follows:

H1: Explicit knowledge sharing direct effect on teacher innovation capability

$\mathrm{H} 2$ : Tacit knowledge sharing direct effect on teacher innovation capability

H3: Explicit knowledge sharing direct effect on organizational culture

H4: Tacit knowledge sharing direct effect on organizational culture

H5: Organizational culture direct effect on teacher innovation capability

H6: Explicit knowledge sharing indirect effect on teacher innovation capability through mediation organizational culture

H7: Tacit knowledge sharing indirect effect on teacher innovation capability through mediation organizational culture

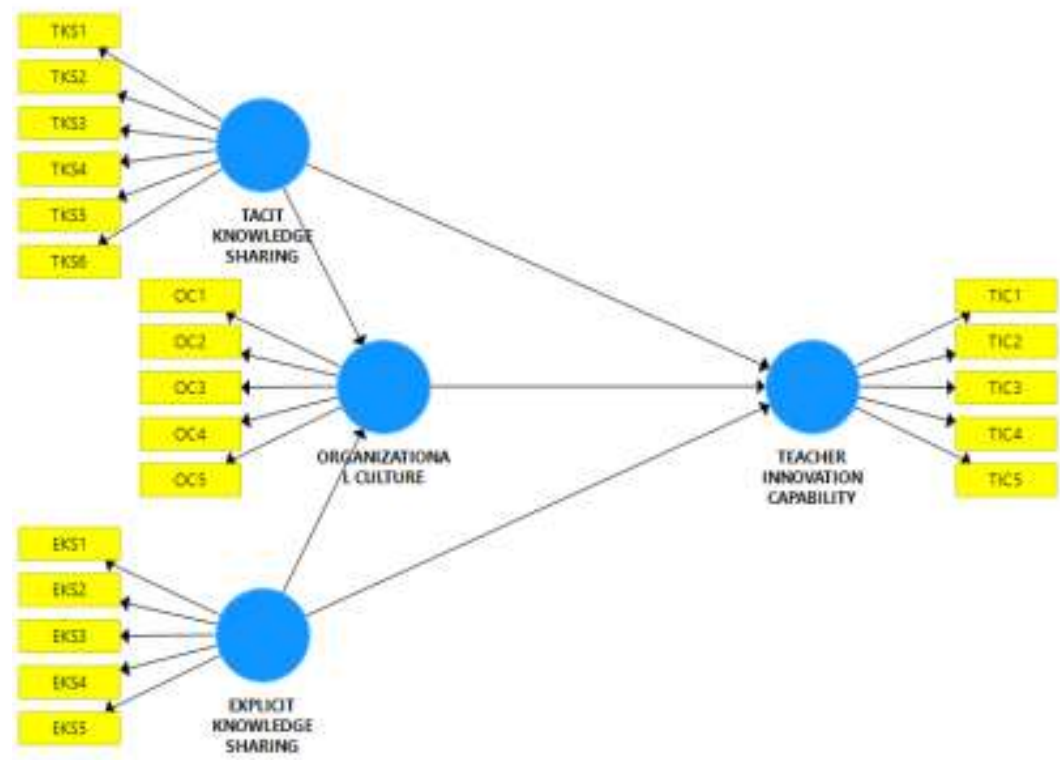

Figure 1. Research Model

\section{LITERATURE REVIEW AND HYPOTHESES DEVELOPMENT}

\section{A. Tacit knowledge}

Knowledge is classified into two types including tacit knowledge and explicit knowledge (Polanyi, 1966). The definition of tacit knowledge is knowledge that is still in the minds of humans and is very personal (Chen et al, 2018; Holford, 2018; Khoshorour \& Gilaninia, 2018; Zebal, Ferdous \& Chambers, 2019; Agyemang \& Boateng, 2019; Perez-Fuillerat et al, 2018), it is difficult to be formulated and divided naturally (Deranek, McLeod \& Schmidt, 2017; Wang \& Liu, 2019; Asher \& Popper, 2019) so that the transformation requires personal interaction (Lee, 2019). This tactical knowledge is rooted in one's actions and experiences, including his ideals, values, and emotions (Boske \& Osanloo, 2015; Kawamura, 2016; Hartley, 2018).

Based on this definition, tacit knowledge is categorized as personal knowledge or in other words knowledge is obtained from individuals or personal (Nonaka \& Toyama, 2015; Munoz et al, 2015; Stewart et al, 2017; Razmerita et al, 2016; Jaleel \& Verghis, 2015; Wang et al., 2016; Serna et al., 2017; Jou et al., 2016; 
Rothberg \& Erickson, 2017). The experience gained by each teacher is certainly different based on situations and conditions that cannot be predicted. Tacit knowledge is not easily articulated and converted to explicit knowledge (Mohajan, 2016; Prasarnphanich et al, 2016; Addis, 2016; Cairo Battistutti, 2017; Zang et al, 2015; Spraggon \& Bodolica, 2017). However, tacit knowledge can be empowered by the process of knowledge spiral or SECI Model (Li, Liu \& Zhou, 2018; Nonaka \& Hirose, 2018; Chatterjee et al, 2018; Sasaki, 2017; Lievre \& Tang, 2015; Stanica \& Peydro, 2016 ; Norwich et al., 2016; Hodgins \& Dadich, 2017; Balde et al., 2018; Okuyama, 2017; Huang et al., 2016).

Every school education institution must utilize its teacher's tacit knowledge by encouraging them to share knowledge and keep learning. School educational institutions like this will become more creative, innovative and lead in the education 4.0. era. Schools can facilitate the management and use of tacit knowledge that is outside the awareness of the subconscious mind of each teacher with an embedding and sharing approach (Ma et al, 2018; Ferreira et al, 2018; Borges et al, 2019; Ferraris et al, 2018; Guo et al, 2018; Tsai \& Hsu, 2019; Swierczek, 2019; Cantwell \& Zaman, 2018).

\section{B. Explicit knowledge}

Explicit knowledge is one type of knowledge that is easily documented and formed (Choi \& Lee, 2003; Sousa \& Rocha, 2019; Borrego et al, 2019; Wokcik et al, 2019; Cifariello, Ferragina \& Ponza, 2019; Che et al, 2018; Tang et al, 2016; Bashir \& Farooq, 2019; Attia \& Salama, 2018), easily articulated (Haamann \& Basten, 2018) and usually constitute knowledge inherent in schools (Afsar, Masood \& Umrani, 2019). In addition, explicit knowledge can be created, written and transferred between school activity units (Lombardi, 2019). The explicit transfer of knowledge among teachers is more easily driven by conducive mechanisms and school culture.

\section{Organizational culture}

A good organizational culture will be more resilient to crises (Starbuck, 2017). Dimensions such as desire, discipline, decision making, and alignment are presented as important elements of organizational learning (Wetzel \& Tint, 2019; Urban \& Gaffurini, 2018). Organizational culture is also an important performance indicator for evaluating overall organizational performance (Qi \& Chau, 2018) that is able to help build the necessary knowledge resources and maintain school growth and continuity. The ability to access knowledge is a distinguishing factor between one school and another. The success of the strategy of school education institutions is very significant related to the solid knowledge base owned by every school educational institution (Asbari, 2019; Asbari, Purwanto, Maesaroh, Hutagalung, Mustikasiwi, et al., 2020; Asbari, Purwanto, \& Budi, 2020 ; Basuki et al., 2020; Bernarto et al., 2020; Fayzhall et al., 2020; Fikri et al., 2020; Goestjahjanti et al., 2020; Kusumaningsih et al., 2020; Nugroho et al., 2020; Prameswari et al., 2020; Pramono et al., 2020; Purba et al., 2020; Purwanto; et al., 2019; Purwanto, Asbari, et al., 2020; Purwanto, Bernarto, et al., 2020; Purwanto , Pramono, et al., 2020; Sutardi et al., 2020; Waruwu et al., 2020; Yanthy et al., 2020).

\section{Teacher Innovation Capability}

4.0. Industrial era currently requires teacher innovation capability as a competitive advantage in schools (Malik, 2019; Muscio \& Ciffolili, 2019; Durana et al, 2019; Lund \& Karlsen, 2019; Haseeb et al, 2019; Jakhar et al, 2018; Hamada, 2019; 2019), competitive strategy (Culot, Orzes \& Sartor, 2019), the key to face 4.0. industry era (Stachova et al, 2019) part of the quality of $21^{\text {st }}$ century management (Gunasekaran, Sabramanian \& Ngai, 2019), has many advantages business (Zambon et al., 2019; Parida, Sjodin \& Reim, 2019). Innovation capability is recognized as one of the most important internal resources that can produce superior school educational institution performance (Zouaghi et al, 2018; Santoro et al, 2017; Castela et al, 2018; Ruiz-Torres et al, 2018; Huesig \& Endres , 2019). Innovation is an important aspect of quality education (Klaeijsen, Vermeulen, \& Martens, 2017) and (Asbari et al., 2019; Asbari, Wijayanti, Hyun, Purwanto, \& Santoso, 2020; Asbari, Wijayanti, Hyun, Purwanto, Santoso, Santoso, et al., 2020; Basuki et al., 2020; Putra et al., 2020).

\section{E. Effect of Tacit and Explicit Knowledge towards Teacher Innovation Capability}

In the industrial 4.0. era which marked by increasingly fierce competition, sustainability remains an important concern and issue. Teacher innovation capability is driving business sustainability. This performance 
depends on the culture of knowledge contained in the organization. Knowledge is consisting of tacit and explicit knowledge. Many researchers discuss teacher innovation capability which concludes that innovation is effected by leadership (Samsir, 2018; Schuckert et al, 2018; Villaluz \& Hechanova, 2019), employee involvement climate (Naqshbandi, Tabche \& Choudhary, 2019) knowledge sharing (Kim \& Shim, 2018) knowledge search (Wang, Chen \& Chang, 2019) collaborative culture (Yang, Nguyen \& Le, 2018) and knowledge process (Imran et al, 2018). This research, would like to examine the effect of tacit and explicit knowledge on teacher innovation capability of teachers in school education institutions in the context of welcoming industrial revolution 4.0. Previous researchers have proven the positive and significant effect of tacit and explicit knowledge on teacher innovation capability (Ganguly et al, 2019; Aulawi, 2018; Rumanti et al, 2018 \& 2019 ; Torres \& Liang, 2016; Li et al, 2019). More specifically, many researchers conclude that tacit knowledge has a positive and significant effect on teacher innovation capability (Perez-Luno et al, 2018). All of them is within the scope of business organizations. However, there are researchers who say that formal \& informal learning affect teacher innovation capability of teachers in schools (Lecat, Beausaert, \& Raemdonck, 2018).

\section{F. Effect of Tacit and Explicit Knowledge towards Organizational Culture}

Learning organization becomes one of the strategies for organizations to study the dynamics of their business environment (Senge, 1990; Zhu et al., 2018; Kasim et al., 2018; Darwish et al., 2018). Schools with managed learning routines will produce a collection of knowledgeable individuals, both explicit knowledge and tacit knowledge (Hussain et al, 2018). Some researchers conclude that organizational culture is effected by collaborative culture and knowledge sharing (Nugroho, 2018). Tacit knowledge was found to be a very significant predictor for the development of organizational culture (Muthuveloo, Shanmugam \& Teoh, 2017).

\section{G. Effect of Organizational Culture towards Teacher Innovation Capability}

Knowledge creation which is conditioned by organizational culture will trigger and spur teacher innovation capability and organizational performance (Asbari, Purwanto \& Santoso, 2019; Vijande \& Sanchez, 2017; Lin \& Lee, 2017). School innovation will be sustainable when it is based on a culture of learning that adds value. This learning culture that makes all teachers interact with each other so that their current knowledge and new knowledge acquired can be effectively transferred, exchanged and combined into school intelligence and knowledge (Lin \& Lee, 2017; Lee et al, 2016; Chang \& Lin , 2015). An organizational environment that provides excitement at work is an important factor in creating teacher innovation capability of organizational members (Bani-Melhem, Zeffane \& Albaity, 2018).

\section{METHODS}

\section{A. Definition of Variable and Indicator Operational}

The method used in this research is quantitative method. Data was collected by distributing questionnaires to all teachers of school education institutions. The instrument used to measure explicit knowledge sharing was adapted from Liebowitz \& Chen (2001) and Wang \& Wang (2012). Tacit knowledge sharing was adapted from Holste \& Fields (2010), Lin (2006), and Wang \& Wang (2012). Organizational culture is measured from instruments adapted from Jiménez-Jiménez and Sanz-Valle (2011). Teacher innovation capability was adapted from Lee \& Choi (2003). The questionnaire was made in closed designed, except for questions / statements about the identity of respondents in the form of a semi-open questionnaire. Each closed question / statement item is given five answer options, namely: strongly agree (SS) score 5, agree (S) score 4, neutral (N) score 3, disagree (TS) score 2, and strongly disagree (STS) score 1. The method for processing data is by PLS and using SmartPLS software version 3.0. as a tool.

\section{B. Population and Sample}

The population in this research was school teachers in Panongan District, Tangerang Indonesia, which numbered 1080 people (Ministry of Education and Culture, 2020). The questionnaire was distributed by simple random sampling technique. The returned and valid questionnaire results were 453 samples (41.95 percent of population). 


\section{A. Sample Description}

\section{RESULTS AND DISCUSSION}

TABLE I

INFORMATION OF DESCRIPTIVE SAMPLE

\begin{tabular}{|c|c|c|c|}
\hline \multicolumn{2}{|c|}{ Criteria } & Amount & $\%$ \\
\hline Age (by October 2019) & $\begin{array}{l}<30 \text { years } \\
30-40 \text { years } \\
>40 \text { years }\end{array}$ & $\begin{array}{c}92 \\
238 \\
123\end{array}$ & $\begin{array}{l}20.31 \% \\
52.54 \% \\
27.15 \%\end{array}$ \\
\hline Teacher Status & $\begin{array}{l}\text { Public (ASN) } \\
\text { Private (Swasta) }\end{array}$ & $\begin{array}{l}171 \\
282\end{array}$ & $\begin{array}{l}37.75 \% \\
62.25 \%\end{array}$ \\
\hline Work service as teacher & $\begin{array}{l}<5 \text { years } \\
5-10 \text { years } \\
>10 \text { years }\end{array}$ & $\begin{array}{c}132 \\
311 \\
10\end{array}$ & $\begin{array}{c}29.14 \% \\
68.65 \% \\
2.21 \%\end{array}$ \\
\hline Hightest educational sertificate & $\begin{array}{l}<\mathrm{S} 1 \\
\geq \mathrm{S} 1\end{array}$ & $\begin{array}{c}31 \\
422\end{array}$ & $\begin{array}{c}6.84 \% \\
93.16 \%\end{array}$ \\
\hline
\end{tabular}

\section{B. Test Results on Validity and Reliability of Research Indicators}

The testing phase of the measurement model includes convergent validity, discriminant validity and composite reliability testing. The results of the PLS analysis can be used to test the research hypothesis if all the indicators in the PLS model have met the requirements of convergent validity, discriminant validity and reliability testing.

\section{Convergent Validity Testing}

Convergent validity test is done by looking at the loading factor value of each indicator to the construct. For most references, a factor weight of 0.5 or more is considered to have validation that is strong enough to explain latent constructs (Chin, 1998; Hair et al, 2010; Ghozali, 2014). In this research the minimum limit on the size of the loading factor received was 0.5 , with the requirement that the AVE value of each construct $>0.5$ (Ghozali, 2014).

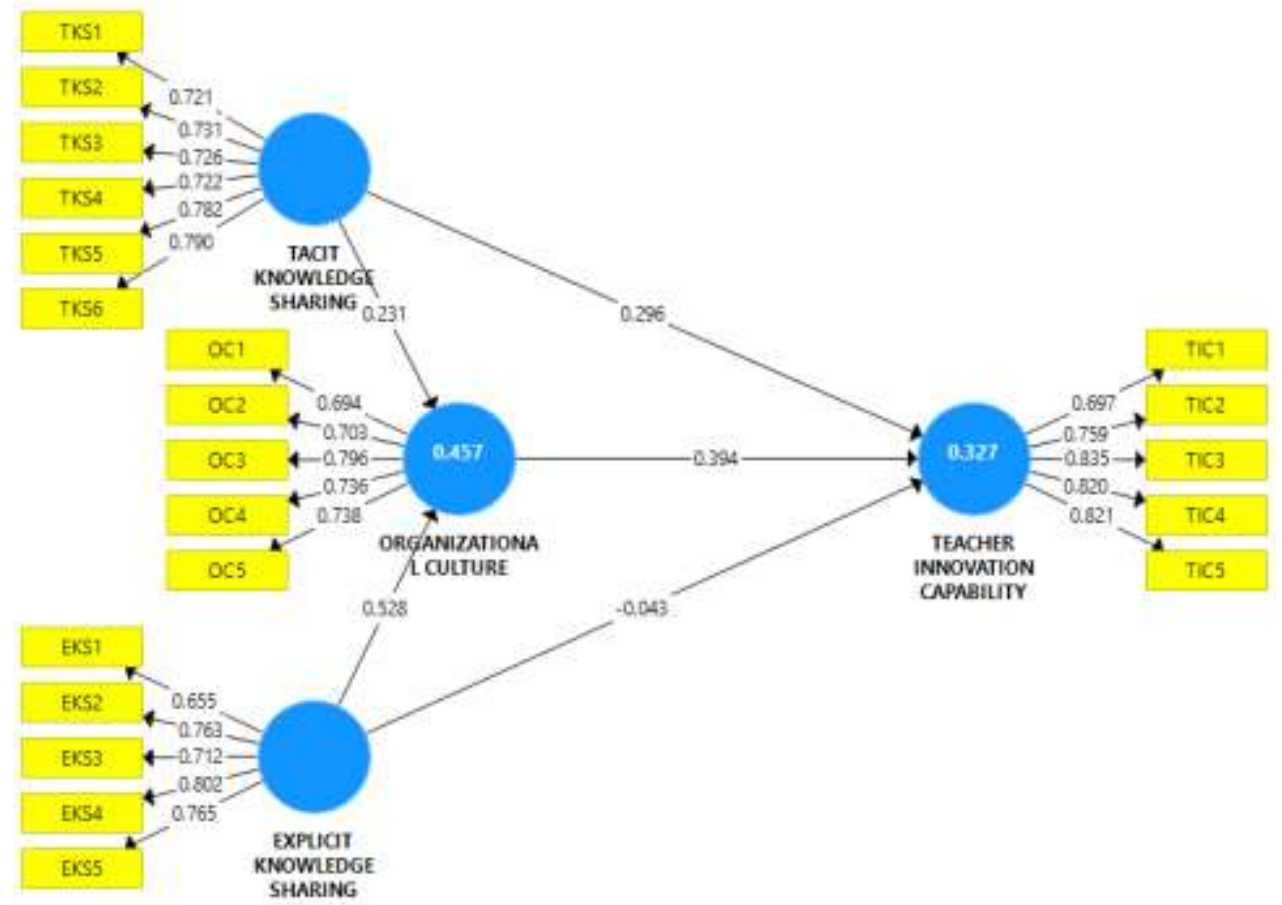

Figure 2. Valid Model Estimation 
Based on the estimation results of the PLS model in the Figure 2, all indicators already have a loading factor value above 0.5 so that the model meets the convergent validity requirements. Apart from looking at the loading factor value of each indicator, convergent validity is also assessed from the AVE value of each construct. AVE value for each contract of this research is above 0.5 . So the convergent validity of this research model meets the requirements. The value of loadings, cronbach's alpha, composite reliability and AVE of each construct can be seen in Table 2 below:

TABLE II

ITEMS LOADINGS, CRONBACH'S ALPHA, COMPOSITE RELIABILITY, AND AVERAGE VARIANCE EXTRACTED (AVE)

\begin{tabular}{|c|c|c|c|c|c|}
\hline Varables & Items & Loadings & $\begin{array}{c}\text { Cronbach's } \\
\text { Alpha }\end{array}$ & $\begin{array}{l}\text { Composite } \\
\text { Reliability }\end{array}$ & AVE \\
\hline \multirow{6}{*}{$\begin{array}{c}\text { Tacit Knowledge Sharing } \\
(T K S)\end{array}$} & TKS1 & 0.721 & 0.842 & 0.882 & 0.556 \\
\hline & TKS2 & 0.731 & & & \\
\hline & TKS3 & 0.726 & & & \\
\hline & TKS4 & 0.722 & & & \\
\hline & TKS5 & 0.782 & & & \\
\hline & TKS6 & 0.790 & & & \\
\hline \multirow{5}{*}{$\begin{array}{c}\text { Explicit Knowledge Sharing } \\
(E K S)\end{array}$} & EKS1 & 0.655 & 0.794 & 0.859 & 0.550 \\
\hline & EKS2 & 0.763 & & & \\
\hline & EKS3 & 0.712 & & & \\
\hline & EKS4 & 0.802 & & & \\
\hline & EKS5 & 0.765 & & & \\
\hline \multirow{5}{*}{$\begin{array}{c}\text { Organizational Culture } \\
(\mathrm{OC})\end{array}$} & OC1 & 0.694 & 0.785 & 0.854 & 0.539 \\
\hline & $\mathrm{OC} 2$ & 0.703 & & & \\
\hline & OC3 & 0.796 & & & \\
\hline & $\mathrm{OC} 4$ & 0.736 & & & \\
\hline & OC5 & 0.738 & & & \\
\hline \multirow{5}{*}{$\begin{array}{c}\text { Teacher Innovation } \\
\text { Capability } \\
\text { (TIC) }\end{array}$} & TIC1 & 0.697 & 0.846 & 0.891 & 0.621 \\
\hline & TIC2 & 0.759 & & & \\
\hline & TIC3 & 0.835 & & & \\
\hline & TIC4 & 0.820 & & & \\
\hline & TIC5 & 0.821 & & & \\
\hline
\end{tabular}

\section{Discriminant Validity Testing}

Discriminant validity is carried out to ensure that each concept of each latent variable is different from the other latent variables. The model has good discriminant validity if the square of AVE values of each exogenous construct (the value on the diagonal) exceeds the correlation between the construct and the other construct (values below the diagonal) (Ghozali, 2014). The results of discriminant validity testing using the AVE squared value by looking at the Fornell-Larcker Criterion Value obtained as follows:

TABLE III

DISCRIMINANT VALIDITY

\begin{tabular}{cccc}
\hline VARIABLES & EKS & OC & TIC \\
\hline EKS & $\mathbf{0 . 7 4 1}$ & $\mathbf{0 . 7 3 4}$ & \\
OC & 0.646 & 0.515 & $\mathbf{0 . 7 8 8}$ \\
TIC & 0.363 & 0.501 & 0.471 \\
\hline
\end{tabular}

The results of the discriminant validity test in Table. 3 above show that all constructs have AVE square root values above the correlation value with other latent constructs (through the Fornell-Larcker criteria) so that it can be concluded that the model meets the discriminant validity.

\section{Construct Reliability Testing}

Construct reliability can be assessed from the value of Cronbach's alpha and composite reliability of each construct. The recommended composite reliability and Cronbach's alpha values are more than 0.7. (Ghozali, 2014). The reliability test results in table 2 above show that all constructs have composite reliability and Cronbach's alpha values greater than 0.7 (> 0.7). In conclusion, all constructs have met the required reliability. 


\section{Hypothesis Testing}

Hypothesis testing in PLS is also called the inner model test. This test includes a test of the significance of direct and indirect effects and measurement of the magnitude of the effect of exogenous variables on endogenous variables. To find out the effect of tacit and explicit knowledge sharing on organizational culture and teacher innovation capability, a direct effect test is needed. The direct effect test is performed using the tstatistic test in the partial least squared (PLS) analysis model using the help of 3.0 Smart PLS software. With the booth strapping technique, R Square values and significance test values are obtained as the table below:

TABLE IV

R SQUARE VALUE

\begin{tabular}{ccc}
\hline & R Square & R Square Adjusted \\
\hline OC & 0.457 & 0.455 \\
TIC & 0.327 & 0.323 \\
\hline
\end{tabular}

TABEL V

HYPOTHESES TESTING

\begin{tabular}{clllccc}
\hline Hypotheses & \multicolumn{1}{c}{ Relationship } & Beta & SE & T Statistics & V-Values & Decision \\
\hline H1 & EKS -> TIC & -0.043 & 0.054 & 0.810 & 0.418 & Not Supported \\
H2 & TKS -> TIC & 0.296 & 0.049 & 6.026 & 0.000 & Supported \\
H3 & EKS -> OC & 0.528 & 0.035 & 15.113 & 0.000 & Supported \\
H4 & TKS -> OC & 0.231 & 0.037 & 6.278 & 0.000 & Supported \\
H5 & OC -> TIC & 0.394 & 0.047 & 8.403 & 0.000 & Supported \\
H6 & EKS -> OC -> TIC & 0.208 & 0.030 & 7.033 & 0.000 & Supported \\
H7 & TKS -> OC -> TIC & 0.091 & 0.018 & 5.057 & 0.000 & Supported \\
\hline
\end{tabular}

Based on Table 4 above, the R Square OC value is 0.457 which means that organizational culture (OC) variables can be explained by tacit knowledge sharing (TKS) and explicit knowledge sharing (EKS) variables by $45.7 \%$, while the remaining $54.3 \%$ is explained by others variables that are not discussed in this research. Meanwhile, the value of R Square teacher innovation capability (TIC) is 0.327 which means that the teacher innovation capability variable is able to explain the tacit knowledge sharing variable, explicit knowledge sharing and organizational culture by $32.7 \%$, while the remaining $67.3 \%$ is explained by other variables not discussed in this research. While Table 5 displays the T Statistics and P-Values which show the effect between the research variables that have been mentioned.

\section{Discussion}

Based on the results of the research, it can be concluded that tacit knowledge sharing has a positive and significant effect on teacher innovation capability, both directly and through organizational culture mediation. This means that the more positive the tacit knowledge sharing is carried out by the teacher, the more conducive the teacher innovation capability of individual teacher of school education institutions will be. This finding is in line with previous research on business organizations, namely Perez-Luno et al (2018), Terhorst et al (2018), Boadu et al (2018), Che et al (2019). In contrast to the above, explicit knowledge sharing does not significantly effect teacher innovation capability, except through mediating organizational culture. That is, organizational culture becomes a full mediation between explicit knowledge sharing and teacher innovation capability.

The results of this research also concluded that tacit and explicit knowledge sharing had a positive and significant effect on organizational culture. This means that the better the tacit and explicit knowledge sharing of a teacher, the more positive the formation and development of organizational culture in school education institutions. This is in line with the conclusions of Qi \& Chau (2018) research on business organizations. This implies that the rarest and most valuable resources in the digital age are not ordinary teachers and mediocre, but teachers who can create new ideas and innovations (Xu, David \& Kim, 2018). Teachers are who play a key role in 
producing and reusing their knowledge and intellectual property through education and teaching (Al-Kurdi, ElHaddadeh \& Eldabi, 2018). For this reason, the scarcity of teachers who have adequate and skilled tacit and explicit knowledge can stifle the power of innovation, competitiveness, growth and flexibility of school education institutions. No doubt, in the future, the talents and responses of school teachers in the process of knowledge sharing will represent an important factor for the nation's future education. School teachers with ideas and innovations will become capital luxury goods and instruments of civilization.

Based on the findings of this research also concluded that organizational culture has a positive and significant effect on teacher innovation capability. Organizational culture also mediates the effect of tacit and explicit knowledge on teacher innovation capability. This is consistent with the conclusion of Martinez-Costa (2018). The research also concluded that school education institutions could manage past experiences to be combined with tacit and explicit knowledge possessed by teachers today. In essence, organizational culture is able to provide positive conditions in the process of knowledge creation. While, knowledge creation and knowledge management are closely related to school performance in the current 4.0 education era.

\section{A. Conclusions}

\section{CONCLUSIONS AND SUGGESTIONS}

The results of this research are tacit knowledge sharing has a positive and significant effect on teacher innovation capability, both directly and through mediating organizational culture. While explicit knowledge sharing only has a positive and significant effect on teacher innovation capability through organizational culture mediation. To add the role of tacit and explicit knowledge sharing as a predictor of teacher innovation capability, schools need to provide autonomy and breadth to share knowledge with teachers. Therefore, schools need to create organizational culture as positive environment that drives the competence and engagement of individual teachers in school education institutions. Indeed knowledge management will run effectively in school education institutions if the individual performance of each teacher is in good condition (Manaf et al, 2017).

Researchers continue to learn about knowledge as an important school resource. It can be said that knowledge sharing, both tacit and explicit knowledge, can significantly improve school performance. Organizational culture transforms individual knowledge into school knowledge. This study concludes that organizational culture acts as a catalyst of the process of knowledge sharing among teachers in schools. This knowledge sharing culture has become crucial in the midst of the development of today's knowledge society. Because in fact, the teacher who carries the obligation to prepare their students to learn and work in this knowledge society.

\section{B. Managerial Implications}

Based on the conclusion of this research, the management of school education institutions needs to build maximum involvement of all teachers to conduct knowledge sharing both in the form of tacit knowledge and explicit knowledge. Teacher training in each section of the school is a necessity with the level of intensity, content and context tailored to the key performance indicators of each teacher. In essence, team learning behavior created in the school environment will be a driving force for teacher innovation (Widmann \& Mulder, 2018).

The process of sharing knowledge to build teacher innovation capability of school education institutions should not only be limited to the internal processes of the school. However, school management needs to expand the process of building this innovation through efforts to absorb, articulate, utilize and manage knowledge sourced from external school partners such as parents, government, communities, and other educational institutions. School management can activate learning from others when assigning their teachers to attend training, seminars, workshops, visits to other schools, meet with school committees and other strategic partners. Because external knowledge, such as those from trainers, coaches, students' parents, the government, the community, and other educational institutions support the teacher innovation capability of school education institutions.

In addition, commitment to learn and serious to be involved in managing the learning environment are things that need attention. Because school education institutions can become organizational culture when all members of the school educational institutions feel that they enjoy the learning process. Learning process becomes a school culture that encourages innovation (Asbari, Santoso \& Purwanto, 2019). The key factors of organizational culture are trust, open communication, high involvement, the presence of industry challenges, 
and a creative work atmosphere. The task of school management is to facilitate the fulfillment of these key factors.

\section{Limitation}

This research has several limitations. First, this research analysis the effect of tacit and explicit knowledge on teacher innovation capability of teachers, both directly and indirectly through organizational culture variables. Because there may be several other variables that affect teacher innovation capability, the researchers strongly recommend finding, exploring and analyzing them. Secondly, this research is conducted in a school educational institution environment and may not be generalized to other industries. Therefore it is highly recommended that further research be carried out on this topic in other industries.

\section{REFERENCES}

[1] Addis, M. (2016) Tacit and explicit knowledge in construction management, Construction Management and Economics, 34:7-8, 439445, DOI: $10.1080 / 01446193.2016 .1180416$

[2] Afsar, B., Masood, M., \& Umrani, W. A. (2019). The role of job crafting and knowledge sharing on the effect of transformational leadership on innovative work behavior. Personnel Review. doi:10.1108/pr-04-2018-0133

[3] Agyemang, F. G., \& Boateng, H. (2019). Tacit knowledge transfer from a master to an apprentice among hairdressers. Education + Training, 61(1), 108-120. doi:10.1108/et-12-2017-0200

[4] Al-Kurdi, O., El-Haddadeh, R., \& Eldabi, T. (2018). Knowledge sharing in higher education institutions: a systematic review. Journal of Enterprise Information Management, 31(2), 226-246. doi:10.1108/jeim-09-2017-0129

[5] Asbari, M. (2015). Fokus Satu Hebat. Penerbit Dapur Buku.

[6] Asbari, M. (2018). Ayah tanpa Wajah. Penerbit Tosca.

[7] Asbari, M. (2019). Pengaruh kepemimpinan transformasional dan iklim organisasi terhadap kinerja dosen. JOCE IP, 13(2), $172-186$. http://jurnal.ipem.ac.id/index.php/joce-ip/article/view/187

[8] Asbari, M., Chi Hyun, C., Wijayanti, L. M., Imelda, D., \& Purwanto, A. (2020). Hard Skills Atau Soft Skills: Manakah Yang Lebih Penting Bagi Inovasi Guru. Edumaspul - Jurnal Pendidikan, 4(1), 1-20. https://www.researchgate.net/publication/339274657_HARD_SKILLS_ATAU_SOFT_SKILLS_MANAKAH_YANG_LEBIH_PEN TING_BAGI_INOVASI_GURU

[9] Asbari, M., Fayzhall, M., Goestjahjanti, F. S., Winanti, Yuwono, T., Hutagalung, D., Basuki, S., Maesaroh, S., Mustofa, Chidir, G., Yani, A., \& Purwanto, A. (2020). Peran Kepemimpinan Transformasional Dan Organisasi Pembelajaran Terhadap Kapasitas Inovasi Sekolah. EduPsyCouns: Journal of Education, Psychology and Counseling, 2(1), 6724-6748. https://ummaspul.ejournal.id/Edupsycouns/article/view/421

[10] Asbari, M., Hyun, C. C., Wijayanti, L. M., WINANTI, W., Fayzhall, M., \& Putra, F. (2020). Hard Skills Dan Soft Skills: Apa Membangun Inovasi Guru Sekolah Islam? Journal EVALUASI, 4(1), 143. https://doi.org/10.32478/evaluasi.v4i1.362

[11] Asbari, M., Purwanto, A., \& Budi, P. (2020). Pengaruh Iklim Organisasi dan Kepemimpinan Transformasional Terhadap Produktivitas Kerja Inovatif Pada Industri Manufaktur di Pati Jawa Tengah . Jurnal Produktivitas, 7(1), 62-69. https://doi.org/http://dx.doi.org/10.29406/jpr.v7i1.1797

[12] Asbari, M., Purwanto, A., Maesaroh, S., Hutagalung, D., Mustikasiwi, A., Ong, F., \& Andriyani, Y. (2020). Impact of Hard Skills, Soft Skills and Organizational Culture $\square$ : Lecturer Innovation Competencies As Mediating. EduPsyCouns: Journal of Education, Psychology and Counseling, 2(1), 142-155. https://ummaspul.e-journal.id/Edupsycouns/article/view/419

[13] Asbari, M., Santoso, P., \& Purwanto, A. (2019). Pengaruh Iklim Organisasi dan Kepemimpinan Transformasional Terhadap Produktivitas Kerja Inovatif Pada Industri Manufaktur di Pati Jawa Tengah. Jurnal Produktivitas Universitas Muhammadiyah Pontianak, 7(1 2020), 62-69. doi: 10.29406/jpr.v7i1.1797

[14] Asbari, M., Santoso, P., and Purwanto, A. (2019). Influence of Leadership, Motivation, Competence, Commitment and Culture on ISO 9001:2015 Performance in Packaging Industry, Scholars Journal of Economics, Business and Management, 6(12): 577-582. DOI: 10.36347/sjebm.2019.v06i12.005

[15] Asbari, M., Santoso, P., and Purwanto, A. (2019). Pengaruh kepemimpinan dan budaya organisasi terhadap perilaku kerja inovatif pada industri 4.0. JIM UPB (Jurnal Ilmiah Manajemen Universitas Putera Batam), 8(1), 7-15. doi:10.33884/jimupb.v8i1.1562

[16] Asbari, M., Wijayanti, L. M., Hyun, C. C., Purwanto, A., Santoso, B., \& Article, H. (2019). Effect of Tacit and Explicit Knowledge Sharing on Teacher Innovation Capability. Dinamika Pendidikan, 14(2), 227-243. https://doi.org/10.15294/dp.v14i2.22732

[17] Asbari, M., Wijayanti, L., Hyun, C. C., Purwanto, A., \& Santoso, P. B. (2020). How to build innovation capability in the RAC industry to face industrial revolution 4.0? International Journal of Psychosocial Rehabilitation, 24(6), $2008-2027$. https://doi.org/10.37200/IJPR/V24I6/PR260192 
[18] Asbari, M., Wijayanti, L., Hyun, C. C., Purwanto, A., Santoso, P. B., Bernarto, I., Pramono, R., \& Fayzhall, M. (2020). The role of knowledge transfer and organizational learning to build innovation capability: Evidence from Indonesian automotive industry. International Journal of Control and Automation, 13(1), 319-333. http://sersc.org/journals/index.php/IJCA/article/view/5732

[19] Asbari, M., Wijayanti,L.M, Hyun, C.C., Purwanto, A., Santoso, P.B,(2020). Effect of Tacit and Explicit Knowledge Sharing on Teacher Innovation Capability, Dinamika Pendidikan, 14(2),47-59, doi: https://doi.org/10.15294/dp.v14i2.22732

[20] Asher, D., \& Popper, M. (2019). Tacit knowledge as a multilayer phenomenon: the "onion" model. The Learning Organization. doi:10.1108/tlo-06-2018-0105

[21] Attia, A. and Salama, I. (2018), "Knowledge management capability and supply chain management practices in the Saudi food industry", Business Process Management Journal, Vol. 24 No. 2, pp. 459-477. https://doi.org/10.1108/BPMJ-01-2017-0001

[22] Aulawi, H. (2018). Improving Teacher innovation capability Trough Creativity and Knowledge Sharing Behavior. IOP Conference Series: Materials Science and Engineering, 434, 012242. doi:10.1088/1757-899x/434/1/012242

[23] Baldé, M., Ferreira, A. and Maynard, T. (2018), "SECI driven creativity: the role of team trust and intrinsic motivation", Journal of Knowledge Management, Vol. 22 No. 8, pp. 1688-1711. https://doi.org/10.1108/JKM-06-2017-0241

[24] Bani-Melhem, S., Zeffane, R. and Albaity, M. (2018), "Determinants of employees' innovative behavior", International Journal of Contemporary Hospitality Management, Vol. 30 No. 3, pp. 1601-1620. https://doi.org/10.1108/IJCHM-02-2017-0079

[25] Bashir, M. and Farooq, R. (2019), "The synergetic effect of knowledge management and business model innovation on firm competence: A systematic review", International Journal of Innovation Science, Vol. 11 No. 3, pp. 362-387. https://doi.org/10.1108/IJIS-10-2018-0103

[26] Basuki, S., Asbari, M., Purwanto, A., Agistiawati, E., Fayzhall, M., Rasyi Radita, F., Maesaroh, S., Wahyuni Asnaini, S., Chidir, G., Yani, A., Singgih, E., Nadhila Sudiyono, R., Sestri Goestjahjanti, F., Yuwono, T., \& Hutagalung, D. (2020). Pengaruh Organizational Culture terhadap Teacher Innovation Capability dalam Perspektif Knowledge Sharing: Studi Kasus Jabodetabek. 19 Februari, 2(1), 171-192. https://ummaspul.e-journal.id/Edupsycouns/article/view/432

[27] Bernarto, I., Bachtiar, D., Sudibjo, N., Suryawan, I. N., Purwanto, A., \& Asbari, M. (2020). Effect of transformational leadership, perceived organizational support, job satisfaction toward life satisfaction: Evidences from indonesian teachers. International Journal of Advanced Science and Technology, 29(3), 5495-5503. http://sersc.org/journals/index.php/IJAST/article/view/6057

[28] Boadu, F., Xie, Y., Du, Y.-F., \& Dwomo-Fokuo, E. (2018). MNEs Subsidiary Training and Development and Firm Innovative Performance: The Moderating Effects of Tacit and Explicit Knowledge Received from Headquarters. Sustainability, 10(11), 4208. doi:10.3390/su10114208

[29] Borges, R., Bernardi, M. and Petrin, R. (2019), "Cross-country findings on tacit knowledge sharing: evidence from the Brazilian and Indonesian IT workers", Journal of Knowledge Management, Vol. 23 No. 4, pp. 742-762. https://doi.org/10.1108/JKM-04-2018-0234

[30] Borrego, G., Morán, A. L., Palacio, R. R., Vizcaíno, A., \& García, F. O. (2019). Towards a reduction in architectural knowledge vaporization during agile global software development. Information and Software Technology. doi:10.1016/j.infsof.2019.04.008

[31] Boske, C. and Osanloo, A. (2015), "Conclusion - Preparing all School Community Leaders to Live their Work", Living the Work: Promoting Social Justice and Equity Work in Schools around the World (Advances in Educational Administration, Vol. 23), Emerald Group Publishing Limited, pp. 405-426. https://doi.org/10.1108/S1479-366020140000023032

[32] Cairó Battistutti, O. \& Bork, D. Cogn Process (2017) 18: 461. https://doi.org/10.1007/s10339-017-0825-6

[33] Cantwell, J. and Zaman, S. (2018), "Connecting local and global technological knowledge sourcing", Competitiveness Review, Vol. 28 No. 3, pp. 277-294. https://doi.org/10.1108/CR-08-2017-0044

[34] Castela, B., Ferreira, F., Ferreira, J. and Marques, C. (2018), "Assessing the teacher innovation capability of small- and mediumsized enterprises using a non-parametric and integrative approach", Management Decision, Vol. 56 No. 6, pp. 1365-1383. https://doi.org/10.1108/MD-02-2017-0156

[35] Chang, C. and Lin, T. (2015), "The role of organizational culture in the knowledge management process", Journal of Knowledge Management, Vol. 19 No. 3, pp. 433-455. https://doi.org/10.1108/JKM-08-2014-0353

[36] Chatterjee, A., Pereira, A. and Sarkar, B. (2018), "Learning transfer system inventory (LTSI) and knowledge creation in organizations", The Learning Organization, Vol. 25 No. 5, pp. 305-319. https://doi.org/10.1108/TLO-06-2016-0039

[37] Che, T., Wu, Z., Wang, Y. and Yang, R. (2019), "Impacts of knowledge sourcing on employee innovation: the moderating effect of information transparency", Journal of Knowledge Management, Vol. 23 No. 2, pp. 221-239. https://doi.org/10.1108/JKM-11-20170554

[38] Che, T., Wu, Z., Wang, Y., \& Yang, R. (2018). Impacts of knowledge sourcing on employee innovation: the moderating effect of information transparency. Journal of Knowledge Management. doi:10.1108/jkm-11-2017-0554

[39] Chen, H., Baptista Nunes, M., Ragsdell, G., \& An, X. (2018). Extrinsic and intrinsic motivation for experience grounded tacit knowledge sharing in Chinese software organisations. Journal of Knowledge Management, 22(2), 478-498. doi:10.1108/jkm-032017-0101

[40] Chin, WW. (1998). The Partial Least Squares Approach to Structural Equation Modeling. Modern Methods for Business Research, In: G. A. Marcoulides, Ed., Lawrence Erlbaum Associates Publisher, New Jersey, pp. 295-336.

[41] Cifariello, P., Ferragina, P., \& Ponza, M. (2019). Wiser: A semantic approach for expert finding in academia based on entity linking. Information Systems, 82, 1-16. doi:10.1016/j.is.2018.12.003 
[42] Culot, G., Orzes, G., \& Sartor, M. (2019). Integration and scale in the context of Industry 4.0: the evolving shapes of manufacturing value chains. IEEE Engineering Management Review, 1-1. doi:10.1109/emr.2019.2900652

[43] Darwish, T. K., Zeng, J., Rezaei Zadeh, M., \& Haak-Saheem, W. (2018). Organizational culture of Absorptive Capacity and Innovation: Does Leadership Matter? European Management Review. doi:10.1111/emre.12320

[44] Deranek, K., McLeod, A., \& Schmidt, E. (2017). ERP Simulation Effects on Knowledge and Attitudes of Experienced Users. Journal of Computer Information Systems, 1-11. doi:10.1080/08874417.2017.1373610

[45] Durana, Kral, Stehel, Lazaroiu, \& Sroka. (2019). Quality Culture of Manufacturing Enterprises: A Possible Way to Adaptation to Industry 4.0. Social Sciences, 8(4), 124. doi:10.3390/socsci8040124

[46] Fayzhall, M., Asbari, M., Purwanto, A., Basuki, S., Hutagalung, D., Maesaroh, S., Chidir, G., Goestjahjanti, F. S., \& Andriyani, Y. (2020). Pengaruh Gaya Kepemimpinan Terhadap Kapabilitas Inovasi Guru Dalam Perspektif Organizational Learning. EduPsyCouns: Journal of Education, Psychology and Counseling, 2(1). https://ummaspul.e-journal.id/Edupsycouns/article/view/413

[47] Ferraris, A., Santoro, G. and Scuotto, V. (2018), "Dual relational embeddedness and knowledge transfer in European multinational corporations and subsidiaries", Journal of Knowledge Management, Vol. ahead-of-print No. ahead-of-print. https://doi.org/10.1108/JKM-09-2017-0407

[48] Ferreira, J., Mueller, J. and Papa, A. (2018), "Strategic knowledge management: theory, practice and future challenges", Journal of Knowledge Management, Vol. ahead-of-print No. ahead-of-print. https://doi.org/10.1108/JKM-07-2018-0461

[49] Fikri, M. A. A., Asbari, M., Purwanto, A., Nugroho, Y. A., Waruwu, H., Fauji, A., Shobihi, A. W., Singgih, E., Sudiyono, R. N., Agistiawati, E., \& Dewi, W. R. (2020). A Mediation Role of Organizational Learning on Relationship of Hard Skills, Soft Skills, Innovation and Performance: Evidence at Islamic School. EduPsyCouns: Journal of Education, Psychology and Counseling, 2(1), 398-423. https://ummaspul.e-journal.id/Edupsycouns/article/view/498

[50] Ganguly, A., Talukdar, A. and Chatterjee, D. (2019), "Evaluating the role of social capital, tacit knowledge sharing, knowledge quality and reciprocity in determining teacher innovation capability of an organization", Journal of Knowledge Management, Vol. 23 No. 6, pp. 1105-1135. https://doi.org/10.1108/JKM-03-2018-0190

[51] Ghozali, I. Structural Equation Modeling, Metode Alternatif dengan Partial Least Square (PLS), Edisi 4. Semarang: Badan Penerbit Universitas Diponegoro. 2014.

[52] Goestjahjanti, F. S., Asbari, M., Purwanto, A., Agistiawati, E., Fayzhall, M., Radita, F. R., Maesaroh, S., Asnaini, S. W., Chidir, G., Yani, A., Singgih, E., Sudiyono, R. N., Basuki, S., Yuwono, T., Hutagalung, D., Wijayanti, L. M., \& Hyun, C. C. (2020). Pengaruh Organizational Learning Terhadap Peningkatan Hard Skills, Soft Skills Dan Inovasi Guru. EduPsyCouns: Journal of Education, Psychology and Counseling, 2(1), 87-97. https://ummaspul.e-journal.id/Edupsycouns/article/view/436

[53] Gunasekaran, A., Subramanian, N., \& Ngai, E. (2018). Quality Management in the 21st Century Enterprises: Research pathway towards Industry 4.0. International Journal of Production Economics. doi:10.1016/j.ijpe.2018.09.005

[54] Guo, Y., Jasovska, P., Rammal, H. and Rose, E. (2018), "Global mobility of professionals and the transfer of tacit knowledge in multinational service firms", Journal of Knowledge Management, Vol. ahead-of-print No. ahead-of-print. https://doi.org/10.1108/JKM-09-2017-0399

[55] Haamann, T., \& Basten, D. (2018). The role of information technology in bridging the knowing-doing gap: an exploratory case study on knowledge application. Journal of Knowledge Management. doi:10.1108/jkm-01-2018-0030

[56] Hair, J. F., Black. W. C., Babin. B. J.; and Anderson. R. E. (2010), Multivariate Data Analysis, 7th ed. New Jersey: Pearson Prentice Hall.

[57] Hamada, T. (2019). Determinants of Decision-Makers' Attitudes toward Industry 4.0 Adaptation. Social Sciences, 8(5), 140. doi: $10.3390 /$ socsci8050140

[58] Hartley, J. (2018), "Ten propositions about public leadership", International Journal of Public Leadership, Vol. 14 No. 4, pp. 202217. https://doi.org/10.1108/IJPL-09-2018-0048

[59] Haseeb, M., Hussain, H. I., Ślusarczyk, B., \& Jermsittiparsert, K. (2019). Industry 4.0: A Solution towards Technology Challenges of Sustainable Business Performance. Social Sciences, 8(5), 154. doi:10.3390/socsci8050154

[60] Hodgins, M. and Dadich, A. (2017), "Positive emotion in knowledge creation", Journal of Health Organization and Management, Vol. 31 No. 2, pp. 162-174. https://doi.org/10.1108/JHOM-06-2016-0108

[61] Holford, W.D. (2018). The future of human creative knowledge work within the digital economy. Futures. doi:10.1016/j.futures.2018.10.002

[62] Holste, J. S., \& Fields, D. (2010). Trust and tacit knowledge sharing and use. Journal of Knowledge Management, 14(1), 128-140. doi:10.1108/13673271011015615

[63] Huang, F., Gardner, S. and Moayer, S. (2016), "Towards a framework for strategic knowledge management practice: Integrating soft and hard systems for competitive advantage", VINE Journal of Information and Knowledge Management Systems, Vol. 46 No. 4, pp. 492-507. https://doi.org/10.1108/VJIKMS-08-2015-0049

[64] Huesig, S. and Endres, H. (2019), "Exploring the digital innovation process: The role of functionality for the adoption of innovation management software by innovation managers", European Journal of Innovation Management, Vol. 22 No. 2, pp. $302-314$. https://doi.org/10.1108/EJIM-02-2018-0051 
[65] Hussain, S. T., Lei, S., Akram, T., Haider, M. J., Hussain, S. H., \& Ali, M. (2018). Kurt Lewin's change model: A critical review of the role of leadership and employee involvement in organizational change. Journal of Innovation \& Knowledge, 3(3), 123-127. doi:10.1016/j.jik.2016.07.002

[66] Imran, M., Ilyas, M., Aslam, U. and Fatima, T. (2018), "Knowledge processes and firm performance: the mediating effect of employee creativity", Journal of Organizational Change Management, Vol. 31 No. 3, pp. 512-531. https://doi.org/10.1108/JOCM10-2016-0202

[67] Jakhar, S. K., Mangla, S. K., Luthra, S., \& Kusi-Sarpong, S. (2018). When stakeholder pressure drives the circular economy. Management Decision. doi:10.1108/md-09-2018-0990

[68] Jaleel, S. and Verghis, A.M. (2015). Knowledge Creation in Constructivist Learning. Universal Journal of Educational Research 3(1): 8-12. doi: 10.13189/ujer.2015.030102.

[69] Jiménez-Jiménez, D., \& Sanz-Valle, R. (2011). Innovation, organizational culture, and performance. Journal of Business Research, 64(4), 408-417. doi:10.1016/j.jbusres.2010.09.010

[70] Jou, M. Lin, Y. and Wu, D. (2016) Effect of a blended learning environment on student critical thinking and knowledge transformation, Interactive Learning Environments, 24:6, 1131-1147, DOI: 10.1080/10494820.2014.961485

[71] Kasim, A., Ekinci, Y., Altinay, L. and Hussain, K. (2018) Impact of market orientation, organizational culture and market conditions on small and medium-size hospitality enterprises, Journal of Hospitality Marketing \& Management, 27:7, 855-875, DOI: $10.1080 / 19368623.2018 .1438955$

[72] Kawamura, K. (2016), "Kristine Marin Kawamura, PhD interviews Ikujiro Nonaka, PhD", Cross Cultural \& Strategic Management, Vol. 23 No. 4, pp. 613-632. https://doi.org/10.1108/CCSM-06-2014-0056

[73] Kementerian Pendidikan dan Kebudayaan. (2020). Data Pokok Pendidikan Dasar dan Menengah. https://dapo.dikdasmen.kemdikbud.go.id/guru/2/280300

[74] Khoshsorour, A., Gilaninia, S. 2018. Kuwait Chapter of the Arabian. Journal of Business and Management Review; Kuwait City 7(3): 1-4. doi: $10.12816 / 0048627$

[75] Kim, N. and Shim, C. (2018). Social capital, knowledge sharing and innovation of small- and medium-sized enterprises in a tourism cluster. International Journal of Contemporary Hospitality Management, Vol. 30 No. 6, pp. 2417-2437. https://doi.org/10.1108/IJCHM-07-2016-0392

[76] Klaeijsen, A., Vermeulen, M., \& Martens, R. (2017). Teachers' Innovative Behaviour: The Importance of Basic Psychological Need Satisfaction, Intrinsic Motivation, and Occupational Self-Efficacy. Scandinavian Journal of Educational Research, 62(5), 769-782. doi:10.1080/00313831.2017.1306803

[77] Kusumaningsih, S. W., Ong, F., Hutagalung, D., Basuki, S., Asbari, M., \& Purwanto, A. (2020). Organizational Culture, Organizational Commitment and Employees ' Performance $\square$ : The Mediating Role of Organizational Citizenship Behavior. TEST $\begin{array}{lllll}\text { Engineering and } & \text { 83(March-April }\end{array}$ http://www.testmagzine.biz/index.php/testmagzine/article/view/6958

[78] Lecat, A., Beausaert, S. \& Raemdonck, I. (2018). On the Relation Between Teachers' (In)formal Learning and Innovative Working Behavior: the Mediating Role of Employability. Vocations and Learning 11, 529-554. doi:10.1007/s12186-018-9199-x

[79] Lee, J.-C., Shiue, Y.-C., \& Chen, C.-Y. (2016). Examining the impacts of organizational culture and top management support of knowledge sharing on the success of software process improvement. Computers in Human Behavior, 54, 462-474. doi:10.1016/j.chb.2015.08.030

[80] Lee, Peter. (2019). Tacit Knowledge and University-Industry Technology Transfer. Research Handbook on Intellectual Property and Technology Transfer (2019, Forthcoming); UC Davis Legal Studies Research Paper Forthcoming. doi: http://dx.doi.org/10.2139/ssrn.3417933

[81] Li, M., Liu, H. and Zhou, J. (2018), "G-SECI model-based knowledge creation for CoPS innovation: the role of grey knowledge", Journal of Knowledge Management, Vol. 22 No. 4, pp. 887-911. https://doi.org/10.1108/JKM-10-2016-0458

[82] Li, Song, Wang, \& Li. (2019). Intellectual Capital, Knowledge Sharing, and Innovation Performance: Evidence from the Chinese Construction Industry. Sustainability, 11(9), 2713. doi:10.3390/su11092713

[83] Liebowitz, J. and Chen, Y. 2001. Developing knowledge-sharing proficiencies. Knowledge Management Review 3(6): 12-15. https://www.researchgate.net/publication/ 285908349_Developing_knowledge-sharing_proficiencies_Building_a_supportive_ culture_for_knowledge-sharing

[84] Lievre, P. and Tang, J. (2015), "SECI and inter-organizational and intercultural knowledge transfer: a case-study of controversies around a project of co-operation between France and China in the health sector", Journal of Knowledge Management, Vol. 19 No. 5 , pp. 1069-1086. https://doi.org/10.1108/JKM-02-2015-0054

[85] Lin, C.-P. (2006). To Share or Not to Share: Modeling Tacit Knowledge Sharing, Its Mediators and Antecedents. Journal of Business Ethics, 70(4), 411-428. doi:10.1007/s10551-006-9119-0

[86] Lin, H., Lee, Y. (2017). A Study of The Influence of Organizational culture on Employees' Innovative Behavior and Work Engagement by A Cross-Level Examination. Eurasia Journal of Mathematics, Science and Technology Education, 13(7), 3463-3478. https://doi.org/10.12973/eurasia.2017.00738a 
[87] Lombardi, R. (2019). Knowledge transfer and organizational performance and business process: past, present and future researches. Business Process Management Journal, 25(1), 2-9. doi:10.1108/bpmj-02-2019-368

[88] Lund, H. B., \& Karlsen, A. (2019). The importance of vocational education institutions in manufacturing regions: adding content to a broad definition of regional innovation systems. Industry and Innovation, 1-20. doi:10.1080/13662716.2019.1616534

[89] Ma, Q., Mayfield, M. and Mayfield, J. (2018), "Keep them on-board! How organizations can develop employee embeddedness to increase employee retention", Development and Learning in Organizations, Vol. 32 No. 4, pp. 5-9. https://doi.org/10.1108/DLO-112017-0094

[90] Malik, A. (2019). Creating competitive advantage through source basic capital strategic humanity in the industrial age 4.0. International Research Journal of Advanced Engineering and Science 4(1): 209-215. www.irjaes.com/pdf/V4N1Y18IRJAES/IRJAES-V4N1P195Y19.pdf

[91] Manaf, H. A., Armstrong, S. J., Lawton, A., \& Harvey, W. S. (2017). Managerial Tacit Knowledge, Individual Performance, and the Moderating Role of Employee Personality. International Journal of Public Administration, 1-13. doi:10.1080/01900692.2017.1386676

[92] Martínez-Costa, M., Jiménez-Jiménez, D., \& Dine Rabeh, H. A. (2018). The effect of organisational learning on interorganisational collaborations in innovation: an empirical study in SMEs. Knowledge Management Research \& Practice, 1-14. doi:10.1080/14778238.2018.1538601

[93] Mohajan, Haradhan (2016): Sharing of Tacit Knowledge in Organizations: A Review. Published in: American Journal of Computer Science and Engineering, Vol. 3, No. 2 (1 July 2016): pp. 6-19. https://mpra.ub.uni-muenchen.de/id/eprint/82958

[94] Muñoz, C.A., Mosey, S. and Binks, M. (2015) The tacit mystery: reconciling different approaches to tacit knowledge. Knowledge Management Research \& Practice, 13:3, 289-298, DOI: 10.1057/kmrp.2013.50

[95] Muscio, A., \& Ciffolilli, A. (2019). What drives the capacity to integrate Industry 4.0 technologies? Evidence from European R\&D projects. Economics of Innovation and New Technology, 1-15. doi:10.1080/10438599.2019.1597413

[96] Muthuveloo, R., Shanmugam, N., \& Teoh, A. P. (2017). The impact of tacit knowledge management on organizational performance: Evidence from Malaysia. Asia Pacific Management Review, 22(4), 192-201. doi:10.1016/j.apmrv.2017.07.010

[97] Naqshbandi, M., Tabche, I. and Choudhary, N. (2019), Managing open innovation: The roles of empowering leadership and employee involvement climate, Management Decision, Vol. 57 No. 3, pp. 703-723. https://doi.org/10.1108/MD-07-2017-0660

[98] Nonaka I., Hirose Nishihara A. (2018) Introduction to the Concepts and Frameworks of Knowledge-Creating Theory. In: Hirose Nishihara A., Matsunaga M., Nonaka I., Yokomichi K. (eds) Knowledge Creation in Community Development. Palgrave Macmillan, Cham. https://doi.org/10.1007/978-3-319-57481-3_1

[99] Nonaka I., Toyama R. (2015) The Knowledge-creating Theory Revisited: Knowledge Creation as a Synthesizing Process. In: Edwards J.S. (eds) The Essentials of Knowledge Management. OR Essentials Series. Palgrave Macmillan, London. https://doi.org/10.1057/9781137552105_4

[100] Norwich, B., Koutsouris, G., Fujita, T., Ralph, T., Adlam, A. and Milton, F. (2016), "Exploring knowledge bridging and translation in lesson study using an inter-professional team", International Journal for Lesson and Learning Studies, Vol. 5 No. 3, pp. 180-195. https://doi.org/10.1108/IJLLS-02-2016-0006

[101] Nugroho, M. (2018), "The effects of collaborative cultures and knowledge sharing on organizational culture", Journal of Organizational Change Management, Vol. 31 No. 5, pp. 1138-1152. https://doi.org/10.1108/JOCM-10-2017-0385

[102] Nugroho, Y. A., Asbari, M., Purwanto, A., Basuki, S., Sudiyono, R. N., Fikri, M. A. A., Hulu, P., Mustofa, Chidir, G., Suroso, \& Xavir, Y. (2020). Transformational Leadership and Employees' Performance: the Mediating Role of Motivation and Work Environment. EduPsyCouns: Journal of Education, Psychology and Counseling, 2(1), 438-460. https://ummaspul.ejournal.id/Edupsycouns/article/view/507

[103] Okuyama, R. (2017), "Importance of tacit knowledge in incremental innovation: Implications from drug discovery cases", Journal of Strategy and Management, Vol. 10 No. 1, pp. 118-130. https://doi.org/10.1108/JSMA-02-2016-0016

[104] Parida, V., Sjödin, D., \& Reim, W. (2019). Reviewing Literature on Digitalization, Business Model Innovation, and Sustainable Industry: Past Achievements and Future Promises. Sustainability, 11(2), 391. doi:10.3390/su11020391

[105] Pérez-Fuillerat, N., Solano-Ruiz, M. C., \& Amezcua, M. (2018). Conocimiento tácito: características en la práctica enfermera. Gaceta Sanitaria. doi:10.1016/j.gaceta.2017.11.002

[106] Pérez-Luño, A., Alegre, J., \& Valle-Cabrera, R. (2018). The role of tacit knowledge in connecting knowledge exchange and combination with innovation. Technology Analysis \& Strategic Management, 1-13. doi:10.1080/09537325.2018.1492712

[107] Polanyi, M. (1966). The Tacit dimension. New York: Doubleday \& Co.

[108] Prameswari, M., Asbari, M., Purwanto, A., Ong, F., Kusumaningsih, S. W., Mustikasiwi, A., Chidir, G., Winanti, \& Sopa, A. (2020). The impacts of leadership and organizational culture on performance in indonesian public health: The mediating effects of innovative work behavior. International Journal of Control and Automation, 13(2), 216-227. http://sersc.org/journals/index.php/IJCA/article/view/7630

[109] Pramono, R., Purwanto, A., Asbari, M., Kotamena, F., Ramdan, M., \& Sihite, O. B. (2020). Nano Perspective for Mentality Revolution Methode of Indonesian Society. International Journal of Advanced Science and Technology, 29(5), 2451-2458. http://sersc.org/journals/index.php/IJAST/article/view/11135 
[110] Prasarnphanich, P., Janz, B. and Patel, J. (2016), "Towards a better understanding of system analysts' tacit knowledge: A mixed method approach", Information Technology \& People, Vol. 29 No. 1, pp. 69-98. https://doi.org/10.1108/ITP-06-2014-0123

[111] Purba, N., Arfanti, Y., Pramono, R., Purwanto, A., Asbari, M., \& Yanthy, E. (2020). Local Wisdom in the Melayunese Shame Culture for Increasing Drug Abuse Eradication in Simalungun. International Journal of Advanced Science and Technology, 29(5), 8135-8140. http://sersc.org/journals/index.php/IJAST/article/view/18461

[112] Purwanto, A., Asbari, M., \& Santoso, P.(2019). Does Culture, Motivation, Competence, Leadership,Commitment Influence Quality Performance?. Jurnal Inovasi Bisnis, 6(2), 201-205. DOI: https://doi.org/10.35314/inovbiz.v7i2.1210

[113] Purwanto, A., Asbari, M., Prameswari, M., Ramdan, M., \& Setiawan, S. (2020). Dampak Kepemimpinan, Budaya Organisasi dan Perilaku Kerja Inovatif Terhadap Kinerja Pegawai Puskesmas. Jurnal Ilmu Kesehatan Masyarakat, 9(01), 19-27. https://doi.org/10.33221/jikm.v9i01.473

[114] Purwanto, A., Bernarto, I., Asbari, M., Wijayanti, L. M., Choi, \&, \& Hyun, C. (2020). The Impacts of Leadership and Culture on Work Performance in Service Company and Innovative Work Behavior As Mediating Effects. Journal of Reseacrh in Business, Economics, and Education, 2(1), 283-291. http://e-journal.stie-kusumanegara.ac.id

[115] Purwanto, A., Pramono, R., Asbari, M., Senjaya, P., Hadi, A. H., \& Andriyani, Y. (2020). Pengaruh Kepemimpinan terhadap Kinerja Guru Sekolah Dasar dengan Keterlibatan Kerja dan Budaya Organisasi sebagai Mediator. EduPsyCouns: Journal of Education, Psychology and Counseling, 2(1), 50-63. https://ummaspul.e-journal.id/Edupsycouns/article/view/412

[116] Purwanto;, A., Asbari;, M., \& Santoso, P. B. (2019). Pengaruh Kompetensi, Motivasi, Kepemimpinan, Komitmen dan Budaya Kerja Sistem Manajemen Integrasi ISO 9001, ISO 14000 dan ISO 45001 pada Industri Otomotif. Jurnal Produktivitas, 6, 158-166. www.openjurnal.unmuhpnk.ac.id/index.php/jp

[117] Putra, A. S., Novitasari, D., Asbari, M., Purwanto, A., Iskandar, J., Hutagalung, D., \& Cahyono, Y. (2020). Examine Relationship of Soft Skills, Hard Skills, Innovation and Performance: the Mediation Effect of Organizational Learning. International Journal of Science and Management Studies (IJSMS), 3(3), 27-43. http://www.ijsmsjournal.org/2020/volume-3 issue-3/ijsms-v3i3p104.pdf

[118] Qi, C. and Chau, P.Y.K. (2018) Will enterprise social networking systems promote knowledge management and organizational culture? An empirical study, Journal of Organizational Computing and Electronic Commerce, 28:1, 31-57, DOI: 10.1080/10919392.2018.1407081

[119] Razmerita L., Phillips-Wren G., Jain L.C. (2016) Advances in Knowledge Management: An Overview. In: Razmerita L., PhillipsWren G., Jain L. (eds) Innovations in Knowledge Management. Intelligent Systems Reference Library, vol 95. Springer, Berlin, Heidelberg. https://doi.org/10.1007/978-3-662-47827-1_1

[120] Rothberg, H. and Erickson, G. (2017), "Big data systems: knowledge transfer or intelligence insights?", Journal of Knowledge Management, Vol. 21 No. 1, pp. 92-112. https://doi.org/10.1108/JKM-07-2015-0300

[121] Ruiz-Torres, A., Cardoza, G., Kuula, M., Oliver, Y. and Rosa-Polanco, H. (2018), "Logistic services in the Caribbean region: An analysis of collaboration, innovation capabilities and process improvement", Academia Revista Latinoamericana de Administración, Vol. 31 No. 3, pp. 534-552. https://doi.org/10.1108/ARLA-03-2017-0078

[122] Rumanti, A. A., Samadhi, T. M. A. A., Wiratmadja, I. I., \& Sunaryo, I. (2018). A systematic literature review on knowledge sharing for innovation: Empirical study approach. 5th International Conference on Industrial Engineering and Applications (ICIEA). doi:10.1109/iea.2018.8387153

[123] Rumanti, A. A., Wiratmadja, I. I., Sunaryo, I., Ajidarma, P., \& Ari Samadhi, T. M. A. (2019). Firm Teacher innovation capability through Knowledge Sharing at Indonesian Small and Medium Industries: Impact of Tacit and Explicit Knowledge Perspective. 2019 IEEE 6th International Conference on Industrial Engineering and Applications (ICIEA). doi:10.1109/iea.2019.8714947

[124] Samsir, S. (2018), The effect of leadership orientation on innovation and its relationship with competitive advantages of small and medium enterprises in Indonesia, International Journal of Law and Management, Vol. 60 No. 2, pp. 530-542. https://doi.org/10.1108/IJLMA-01-2017-0005

[125] Santoro, G., Vrontis, D., Thrassou, A., \& Dezi, L. (2017). The Internet of Things: Building a knowledge management system for open innovation and knowledge management capacity. Technological Forecasting and Social Change. doi:10.1016/j.techfore.2017.02.034

[126] Sasaki, Y. (2017), "A note on systems intelligence in knowledge management", The Learning Organization, Vol. 24 No. 4, pp. 236244. https://doi.org/10.1108/TLO-09-2016-0062

[127] Schuckert, M., Kim, T., Paek, S. and Lee, G. (2018), "Motivate to innovate: How authentic and transformational leaders influence employees' psychological capital and service innovation behavior", International Journal of Contemporary Hospitality Management, Vol. 30 No. 2, pp. 776-796. https://doi.org/10.1108/IJCHM-05-2016-0282

[128] Serna M., E., Bachiller S., O., \& Serna A., A. (2017). Knowledge meaning and management in requirements engineering. International Journal of Information Management, 37(3), 155-161. doi:10.1016/j.ijinfomgt.2017.01.005

[129] Sopa, A., Asbari, M., Purwanto, A., Budi Santoso, P., Mustofa, Hutagalung, D., Maesaroh, S., Ramdan, M., \& Primahendra, R. (2020). Hard skills versus soft skills: Which are more important for indonesian employees innovation capability. International Journal of Advanced Science and Technology, 29(3), 6431-6453. http://sersc.org/journals/index.php/IJAST/article/view/7233

[130] Sousa, M. J., \& Rocha, Á. (2019). Strategic Knowledge Management in the Digital Age. Journal of Business Research, 94, $223-226$. doi:10.1016/j.jbusres.2018.10.016 
[131] Spraggon, M. and Bodolica, V. (2017), "Collective tacit knowledge generation through play: Integrating socially distributed cognition and transactive memory systems", Management Decision, Vol. 55 No. 1, pp. 119-135. https://doi.org/10.1108/MD-05-2015-0173

[132] Stachová, K., Papula, J., Stacho, Z., \& Kohnová, L. (2019). External Partnerships in Employee Education and Development as the Key to Facing Industry 4.0 Challenges. Sustainability, 11(2), 345. doi:10.3390/su11020345

[133] Stanica, S. and Peydro, J. (2016), "How does the employee cross-training lean tool affect the knowledge transfer in product development processes?", VINE Journal of Information and Knowledge Management Systems, Vol. 46 No. 3, pp. 371-385. https://doi.org/10.1108/VJIKMS-11-2015-0061

[134] Starbuck, W. (2017), "Organizational culture and unlearning", The Learning Organization, Vol. 24 No. 1, pp. 30-38. https://doi.org/10.1108/TLO-11-2016-0073

[135] Stewart, C., Schiavon, L.M. and Bellotto, M.L. (2017) Knowledge, nutrition and coaching pedagogy: a perspective from female Brazilian Olympic gymnasts, Sport, Education and Society, 22(4): 511-527, DOI: 10.1080/13573322.2015.1046428

[136] Sutardi, D., Novitasari, D., Asbari, M., Silitonga, N., Nugroho, Y. A., Hutagalung, D., Mustofa, Chidir, G., Basuki, S., \& Yuwono, T. (2020). Pengaruh Work-Family Conflict, Stres Kerja dan Social Support terhadap Kepuasan Kerja: Studi Kasus pada Guru Wanita di Tangerang. EduPsyCouns: Journal of Education, Psychology and Counseling, 2(1), 482-498. https://ummaspul.ejournal.id/Edupsycouns/article/view/513

[137] Swierczek, A. (2019), "Manufacturer structural embeddedness and the network rent: the intervening role of relational embeddedness in the triadic supply chains", Supply Chain Management, Vol. 24 No. 3, pp. 334-354. https://doi.org/10.1108/SCM-06-2018-0232

[138] Tang, V., Yanine, F. and Valenzuela, L. (2016), "Data, information, knowledge and intelligence: The mega-nano hypothesis and its implications in innovation", International Journal of Innovation Science, Vol. 8 No. 3, pp. 199-216. https://doi.org/10.1108/IJIS-072016-0022

[139] Terhorst, A., Lusher, D., Bolton, D., Elsum, I., \& Wang, P. (2018). Tacit Knowledge Sharing in Open Innovation Projects. Project Management Journal, 49(4), 5-19. doi:10.1177/8756972818781628

[140] Torres, O. J. J., \& Liang, D. (2016). Knowledge Sharing and the Teacher innovation capability of Chinese Firms: The Role of Guanxi. 2016 International Conference on Industrial Engineering, Management Science and Application (ICIMSA). doi:10.1109/icimsa.2016.7504015

[141] Tsai, F. and Hsu, I. (2019), "The effects of social capital on knowledge heterogeneity", Management Decision, Vol. 57 No. 5, pp. 1237-1253. https://doi.org/10.1108/MD-12-2016-0909

[142] Urban, B. and Gaffurini, E. (2018), "Social enterprises and organizational culture in South Africa", Journal of Entrepreneurship in Emerging Economies, Vol. 10 No. 1, pp. 117-133. https://doi.org/10.1108/JEEE-02-2017-0010

[143] Vijande M.L.S., Sánchez J.Á.L. (2017) The Effects of Organizational culture on Innovation and Performance in Kibs: An Empirical Examination. In: Campbell C.L. (eds) The Customer is NOT Always Right? Marketing Orientationsin a Dynamic Business World. Developments in Marketing Science: Proceedings of the Academy of Marketing Science. Springer, Cham. https://doi.org/10.1007/978-3-319-50008-9_227

[144] Villaluz, V. and Hechanova, M. (2019), "Ownership and leadership in building an innovation culture", Leadership \& Organization Development Journal, Vol. 40 No. 2, pp. 138-150. https://doi.org/10.1108/LODJ-05-2018-0184

[145] Wang, C., Chen, M. and Chang, C. (2019), "The double-edged effect of knowledge search on innovation generations", European Journal of Innovation Management, Vol. ahead-of-print No. ahead-of-print. https://doi.org/10.1108/EJIM-04-2018-0072

[146] Wang, J., \& Liu, L. (2019). Study on the mechanism of customers' participation in knowledge sharing. Expert Systems, e12367. doi:10.1111/exsy. 12367

[147] Wang, X., Arnett, D. and Hou, L. (2016), "Using external knowledge to improve organizational innovativeness: understanding the knowledge leveraging process", Journal of Business \& Industrial Marketing, Vol. 31 No. 2, pp. 164-173. https://doi.org/10.1108/JBIM-04-2014-0064

[148] Wang, Z., \& Wang, N. (2012). Knowledge sharing, innovation and firm performance. Expert Systems with Applications, 39(10), 8899-8908. doi:10.1016/j.eswa.2012.02.017

[149] Waruwu, H., Asbari, M., Purwanto, A., Nugroho, Y. A., Fikri, M. A. A., Fauji, A., Shobihi, A. W. I., Hulu, P., Sudiyono, R. N., Agistiawati, E., \& Dewi, W. R. (2020). The Role of Transformational Leadership, Organizational Learning and Structure on Innovation Capacity: Evidence from Indonesian Private Schools. EduPsyCouns: Journal of Education, Psychology and Counseling, 2(1), 378-397. https://ummaspul.e-journal.id/Edupsycouns/article/view/499

[150] Wetzel R., Tint B. (2019) Using Applied Improvisation for Organizational culture in the Red Cross Red Crescent Climate Centre. In: Antonacopoulou E., Taylor S. (eds) Sensuous Learning for Practical Judgment in Professional Practice. Palgrave Studies in Business, Arts and Humanities. Palgrave Macmillan, Cham. https://doi.org/10.1007/978-3-319-99049-1_3

[151] Widmann, A. and Mulder, R. (2018), "Team learning behaviours and innovative work behaviour in work teams", European Journal of Innovation Management, Vol. 21 No. 3, pp. 501-520. https://doi.org/10.1108/EJIM-12-2017-0194

[152] Wójcik, M., Jeziorska-Biel, P., \& Czapiewski, K. (2019). Between words: A generational discussion about farming knowledge sources. Journal of Rural Studies, 67, 130-141. doi:10.1016/j.jrurstud.2019.02.024

[153] Xu, M., David, J. M., \& Kim, S. H. (2018). The Fourth Industrial Revolution: Opportunities and Challenges. International Journal of Financial Research, 9(2), 90. doi:10.5430/ijfr.v9n2p90 
[154] Yang, Z., Nguyen, V. and Le, P. (2018), Knowledge sharing serves as a mediator between collaborative culture and teacher innovation capability: an empirical research, Journal of Business \& Industrial Marketing, Vol. 33 No. 7, pp. 958-969. https://doi.org/10.1108/JBIM-10-2017-0245

[155] Yanthy, E., Purwanto, A., Pramono, R., Cahyono, Y., \& Asbari, M. (2020). Pengaruh Gaya Kepemimpinan Transformasional dan Tranksaksional Terhadap Kinerja Sistem Jaminan Halal HAS 23000. Jurnal Bisnis Dan Manajemen Islam, 8(1). https://doi.org/http://dx.doi.org/10.21043/bisnis.v8i1.7045

[156] Zambon, I., Cecchini, M., Egidi, G., Saporito, M. G., \& Colantoni, A. (2019). Revolution 4.0: Industry vs. Agriculture in a Future Development for SMEs. Processes, 7(1), 36. doi:10.3390/pr7010036

[157] Zebal, M., Ferdous, A., \& Chambers, C. (2019). An integrated model of marketing knowledge - a tacit knowledge perspective. Journal of Research in Marketing and Entrepreneurship. doi:10.1108/jrme-03-2018-0018

[158] Zhang, C., Xiao, H., Gursoy, D. and Rao, Y. (2015). Tacit knowledge spillover and sustainability in destination development. Journal of Sustainable Tourism, 23:7, 1029-1048, DOI: 10.1080/09669582.2015.1032299

[159] Zhu, Q., Krikke, H. and Caniëls, M. (2018), Supply chain integration: value creation through managing inter-organizational culture. International Journal of Operations \& Production Management, Vol. 38 No. 1, pp. 211-229. https://doi.org/10.1108/IJOPM-062015-0372

[160] Zouaghi, F., Sánchez, M., \& Martínez, M. G. (2018). Did the global financial crisis impact firms' innovation performance? The role of internal and external knowledge capabilities in high and low tech industries. Technological Forecasting and Social Change, 132, 92-104. doi:10.1016/j.techfore.2018.01.011 